Int. J. Dev. Biol. 55: 969-974

doi: $10.1387 / \mathrm{ijdb} .1134241 \mathrm{~s}$

\title{
A non-enzymatic microsurgical dissection technique of mouse embryonic tissues for gene expression profiling applications
}

\author{
LI SUN, MAY-YIN LEE and JACQUELINE M. VELTMAAT* \\ Institute of Molecular and Cell Biology, A*STAR (Agency for Science, Technology and Research), Singapore.
}

\begin{abstract}
With the increased use of gene expression profiling to identify molecular regulators of cellular and developmental mechanisms, developmental biologists face a new challenge in dissecting tissues without cross-contamination or change in RNA profile, and with intact RNA integrity. We have developed a technique that overcomes these problems. We took the dissection of rudimentary mouse embryonic mammary glands as an example, as these structures are particularly difficult to separate from their contiguous ectoderm and strongly adhering mesenchyme. Contrary to conventional enzymatic tissue-separation methods, we blocked transcriptional activity prior to dissection and protected RNA from degradation during dissection, by the use of RNAlater. While RNAlater dehydrates specimens so severely that it interferes with visibility and clean dissection of organs or tissues, we established rehydration conditions that in fact facilitated tissue separation and shortened dissection time to about $\mathbf{1 0}$ minutes. The extracted RNA had an excellent quality, rendering it perfectly suitable for transcriptional profiling. Visual inspection of separated tissues and tissue specific gene expression analysis by microarray and RT-PCR confirmed that the tissues were separated with minimal or no cross-contamination. We show that this dissection method can be applied to a broad variety of organs, and that the tissue is still amenable to protein detection. In conclusion, this is a rapid, cheap and effective non-enzymatic tissue separation method which greatly facilitates the exploration of molecular mechanisms in organ formation.
\end{abstract}

KEY WORDS: tissue separation, dissection, mouse embryo, gene expression profiling, RNAlater

\section{Introduction}

Gene expression profiling has become a very popular method to identify novel regulators of cell fate decisions and developmental processes. To acquire meaningful profiles, two prerequisites must be met: The cells of interest have to be obtained with minimal or preferably no contamination from other cells and their extracted RNA has to be of high quality.

Obtaining an organ or tissue as a non-contaminated cell population from an organism can be challenging. Especially when the organ or tissue of interest is small, any contamination by adjacent tissues can easily create considerable artefacts in gene expression analysis. Examples of such challenging tissues are mouse embryonic skin appendages such as mammary rudiments (Mikkola, 2007, Tucker, 2007, Veltmaat et al., 2003). They arise around E11.5 as placodal structures without clear boundaries in the surface ectoderm of the flank (Fig. 1A). One day later, the placodes have transformed into hillocks or buds as small as 100 to $200 \mu \mathrm{m}$ in diameter (Fig. 1B). While the boundaries of the mammary rudiment are now clearer, which facilitates dissection, the rudiments are still in continuum with the adjacent surface ectoderm, and they are tightly connected to the surrounding mesenchyme. With plain microsurgical techniques, the mesenchyme cannot be separated from the overlying ectoderm with appendages, or from the underlying somites.

To date, methods to separate these - and other - epithelia from their adjacent mesenchyme rely on digestion of the bonds between epithelium and mesenchyme by exogenously applied enzymes, followed by recovery in serum and subsequent microsurgical separation (Kratochwil and Schwartz, 1976). Such enzymatic tissue

Abbreviations used in this paper: Cdh1, E-cadherin; Krt5, keratin 5.

\footnotetext{
*Address correspondence to: Jacqueline M. Veltmaat. A*STAR Institute of Molecular and Cell Biology, 61 Biopolis Drive, Proteos 6-06B, Singapore 138673. Tel.: +65-6586-9618. Fax: +65-6779-1117. e-mail: jveltmaat.sc@gmail.com
} 
separation is compatible with preservation of tissue viability, and is therefore an advantageous method of separation if tissues are to be used in e.g. heterotypic tissue recombination and culture assays (Kratochwil and Schwartz, 1976). Although this method may also be used for gene expression analysis (Wansbury et al., 2011), it then has the disadvantage of requiring additional control samples and validation steps, because the treatments and dissection time allow ample opportunity for transcriptional responses to occur (Amit et al., 2007). Blocking RNA transcription by intermediate lysis is incompatible with subsequent separation of joined tissues. Other conventional methods to block transcription, e.g. tissue fixation and snap-freezing, are compatible with laser capture microdissection (LCM) to isolate the cells or tissue of interest for subsequent RNA analysis (Emmert-Buck et al., 1996), but LCM has several disadvantages: The equipment is expensive; LCM itself is a timeconsuming method as it requires embedding and sectioning of the specimens, and staining of the sections; the amount of work is multiplied with every section from which the tissue has to be dissected; and these manipulations and the time involved result in RNA degradation and consequential bias in gene expression profiling analysis, in particular when the microdissected areas are small and dissected with a UV laser (Copois et al., 2007). We sought to develop a tissue isolation technique that bypasses all problems associated with the aforementioned techniques.

We reached our goal by collecting mouse embryos in RNAlater to block RNA transcription and degradation. Although RNAlater severely dehydrates specimens, making recognition and dissection of tissues impossible, we identified an optimal partial rehydration condition which preserves RNA integrity while making individual organs and tissues visible again. Under these conditions, we reproducibly and cleanly separated the mammary rudiments, ectoderm and mesenchyme from each other via microsurgical techniques, and obtained good RNA yields with excellent integrity. We show that this technique is applicable to other organs and tissues as well. As moreover, this dissection technique requires no specialized expensive equipment, and is carried out much more rapidly than enzymatic dissection techniques, it is an excellent alternative to existing methods for molecular studies of developmental mechanisms.

\section{Experimental Protocols}

\section{RNase-free experimental environments}

Working surfaces (e.g. Bench and stereoscope) were wiped with RNase AWAY (Molecular BioProduct). All the dissecting instruments (e.g. forceps, knives, scissors and spoon) were sterilized using GERMINATOR 500 (Cellpoint Scientific) for $30 \mathrm{~min}$ and cleaned with RNase AWAY. PBS with $\mathrm{Mg}^{2+}$ and $\mathrm{Ca}^{2+}$ (Sigma-Aldrich) was treated overnight with $1 / 1000$ (v/v) Diethylpyrocarbonate (DEPC) (Invitrogen), and autoclaved. Hereafter it is referred to as DEPC$\mathrm{PBS}^{+/+}$. Gloves were worn at all times and replaced regularly.

\section{Mouse breeding and embryo collection in RNAlater}

C57BI/6J mice were maintained according to IACUC regulations, under normal day-night cycle, with food and water ad libitum. At the day a vaginal plug was observed during timed matings, noon was considered embryonic day (E) 0.5 . Female mice were sacrificed by cervical dislocation at the required day of pregnancy. The embryos were then collected and washed 3 times in fresh batches of cold
DEPC-PBS ${ }^{+/+}$. After a brief rinse with RNAlater, the embryos were transferred into 5 to 10 volumes of RNAlater (Ambion) to be kept at $4^{\circ} \mathrm{C}$ overnight, divided over several microfuge tubes (e.g. 2 E13.5 or 3 E12.5 embryos per $2 \mathrm{ml}$ tube with RNAlater) and stored at $-80^{\circ} \mathrm{C}$ until further use.

\section{Microdissection and lysis of ectoderm, mammary buds, and dermal mesenchyme}

Tubes containing embryos in RNAlater were thawed on ice and embryos were transferred one at a time to a $35 \mathrm{~mm}$ petri-dish containing sufficient RNAlater at room temperature to submerge the embryo (Fig. 1C). Microdissection was then performed under the Leica MZ16 stereoscope.

\section{Rough dissection}

The head and tail were cut off, after which the remainder of the embryo was cut into half along the neural tube and ventral midline, using two Graeffe knives. Then the limb buds and internal organs were removed with two pairs of \#5 Dumont forceps. Somitic mesoderm was further peeled away with the forceps until both flanks consisted of only ectoderm and dermal mesenchyme (Fig. 1D). At this moment the mammary buds could not be observed because of the extreme dehydrating effect of RNAlater, which also made separation of ectoderm and mesenchyme still difficult (Fig. 1E).

\section{Rehydration and precise dissection}

One of the cleared flanks was transferred to a new $35 \mathrm{~mm}$ petri-dish containing 40\% RNAlater (4 volumes RNAlater and 6 volumes DEPC-PBS ${ }^{+/+}$). This facilitated rehydration of the tissue within 5 minutes, such that the ectoderm could easily be peeled off from the underlying mesenchyme using two pairs of \#5 Dumont forceps. Meanwhile, the five mammary buds became visible (Fig. $1 \mathrm{~F})$. During separation of the ectoderm from the mesenchyme, mammary buds 1, 2, 4, and 5 remained attached to the adjacent ectoderm, from which they were subsequently carefully removed using forceps (Fig. 1G). However, most often bud 3 broke off from the ectoderm and was retained by the mesenchyme. It was easily liberated by placing the two 'legs' of the forceps in the mesenchyme on either side of the bud and lightly squeezing the mesenchyme. After bud collection, cup shaped cavities were observed in the mesenchyme where the buds previously resided (Fig. 1G). Mesenchymal samples were collected by placing the legs of one pair of Dumont \#5 forceps at opposite positions in the mesenchyme very close to the edge of a cavity, and squeezing the tips together.

\section{TABLE 1}

\section{PRIMER SEQUENCES}

\begin{tabular}{|c|c|c|c|}
\hline Gene & Primer sequence (5'---->3') & $\begin{array}{l}\text { Product } \\
\text { length (bp) }\end{array}$ & $\begin{array}{l}\text { Reference } \\
\text { sequence }\end{array}$ \\
\hline Krt5 & $\begin{array}{l}\text { F: CTCCAGGAACCATCATGTCTCGCCAGTC } \\
\text { R: CACCACCGAAGCCAAAGCCACTACCAG }\end{array}$ & 354 & NM_027011 \\
\hline Edar & $\begin{array}{l}\text { F: CGACGCTGAGTGTGGCCCAT } \\
\text { R: GTCACCACACTGTCTGGGGCCT }\end{array}$ & 417 & NM_010100 \\
\hline Pthlh & $\begin{array}{l}\text { F: CCCTCGCATCCACGACACGC } \\
\text { R: GACACAGCGCGTTTGAGCCTG }\end{array}$ & 558 & NM_008970 \\
\hline Pth1r & $\begin{array}{l}\text { F: GCAGAGATTAGGAAGTCTTGGA } \\
\text { R: AGCCGTCGTCCTTGGGAACTGT }\end{array}$ & 280 & NM_011199 \\
\hline Twist2 & $\begin{array}{l}\text { F: CCCCACGCTCCCCTCTGACAA } \\
\text { R: TGTGCAGGTGGGTCCTGGCTT }\end{array}$ & 258 & NM_007855 \\
\hline Trp63 & $\begin{array}{l}\text { F: TCAGTTGGAGCAAGGGGGACA } \\
\text { R: GGGGTTTCTATGAAACGCTGGATGT }\end{array}$ & 528 & NM_001127259 \\
\hline
\end{tabular}


While the specimen was held down with another forceps, the cavity was then pulled out, with some surrounding mesenchyme remaining attached to it $(\mathrm{Fig} .1 \mathrm{H})$. By visual inspection, the attached mesenchyme consisted primarily of the more dense mesenchyme, which is otherwise known as the mammary mesenchyme based on its higher condensation, and expression of differentiation markers such as Estrogen Receptor and Androgen Receptor that are absent from the dermal mesenchyme (Fig. 1B). The thickness and shape of the collected mesenchymal cups varied slightly, along with the variation in shape of the five mammary buds and their adjacent mammary mesenchyme (Lee et al., 2011), but was fairly consistent among replicates of the same bud.

\section{Lysis}

The dissected tissues were aspirated immediately after dissection with a minimal (e.g. $2 \mu \mathrm{l}$ ) volume of $40 \%$ RNAlater using a $0.5-10 \mu \mathrm{l}$ pipette, and released into 50 to $100 \mu \mathrm{l}$ RLT plus lysis buffer from the RNeasy Micro Plus Kit (Qiagen).

\section{RNA isolation and cDNA microarray}

Total RNA was extracted using the RNeasy Micro Plus Kit (Qiagen). Briefly, the mammary buds (10 per embryo), their adjacent ectoderm and mesenchyme from 3 embryos were pooled by tissue type and lysed in $350 \mu$ l lysis buffer respectively, and total RNA was eluted in $14 \mu \mathrm{l}$ of Elution buffer. RNA concentrations were determined using the NanoDrop ND-1000 (Thermo Scientific); concentrations of mammary bud RNA were above $3.3 \mathrm{ng} / \mu \mathrm{l}$ or 1.1 to $1.67 \mathrm{ng}$ RNA per bud. RNA quality was analyzed by RNAelectrophoresis on RNA 6000 Pico Chips in the Agilent 2100 Bioanalyzer (Agilent Technologies). $10 \mathrm{ng}$ of total RNA with RIN $>9$ were used to initiate cDNA amplification using the WT-Ovation ${ }^{\mathrm{TM}}$ Pico RNA Amplification System (NuGene Technologies). $3 \mu \mathrm{g}$ of amplified cDNA were converted to sense strand cDNA using WT-Ovation ${ }^{\text {TM }}$ Exon Module (NuGene Technologies) followed by fragmentation and labeling with FL-Ovation ${ }^{\mathrm{TM}}$ cDNA Biotin Module V2 (NuGene Technologies). The biotin-labeled cDNA fragments were hybridized to Affymetrix Mouse Gene 1.0 ST Array chips (Affymetrix).

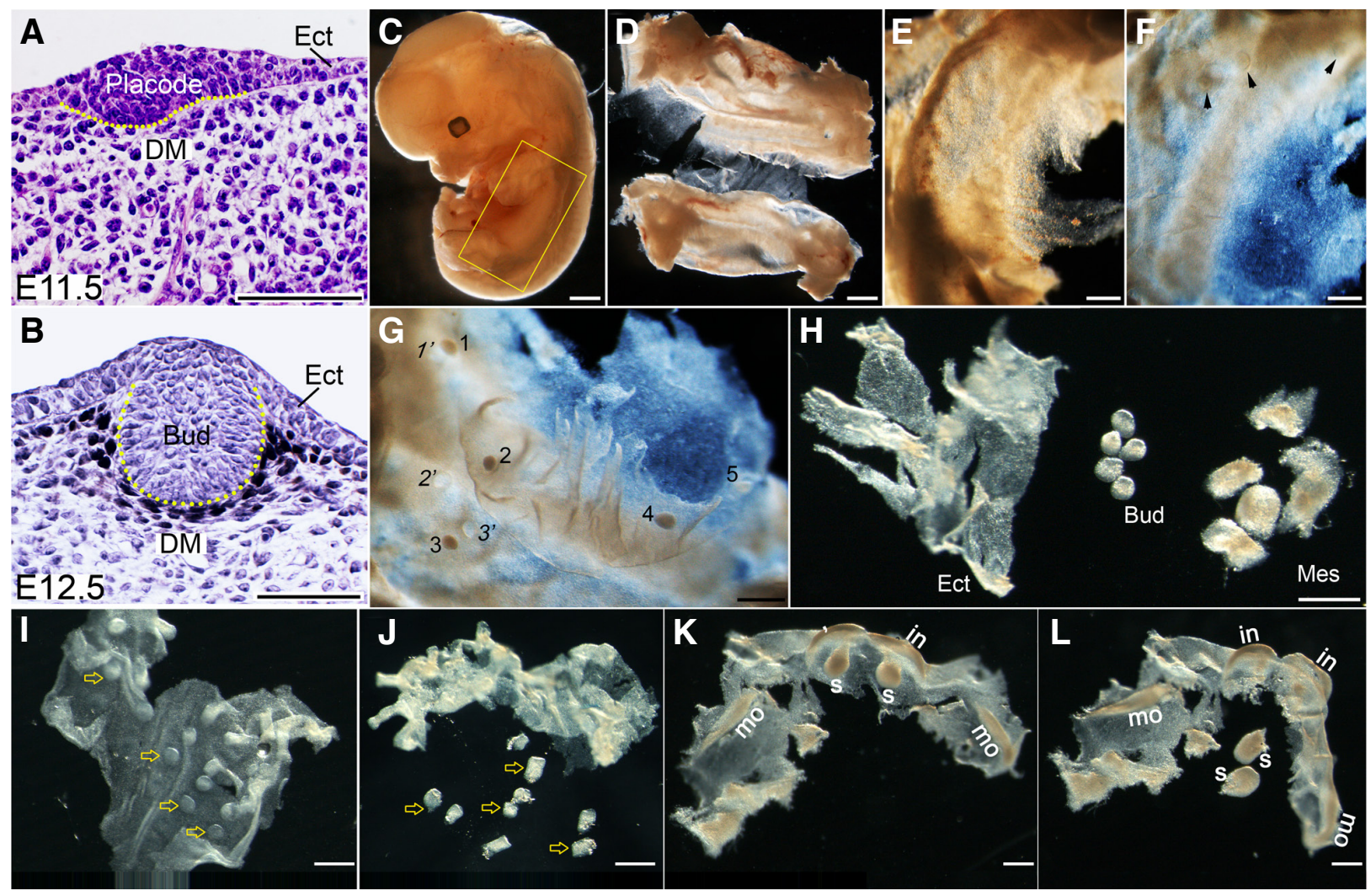

Fig. 1. Microdissection of ectodermal appendages from E12.5 mouse embryo. (A,B) Images of 6 um sections of $4 \%$ PFA fixed, paraffin embedded mouse embryos showing part of the flank with the boundary of a mammary rudiment indicated by the yellow dashed line. (A) Haematoxylin/Eosin stained section visualizing an E11.5 mammary placode and its lack of a clear boundary with the surface ectoderm. (B) Haematoxylin counterstained section showing an E12.5 mammary bud as a distinct epithelial entity within the surface ectoderm, and visualizing the mammary mesenchyme by detection of Androgen Receptor expression (black). (C-L) Microdissection procedure of E12.5 mammary buds. (C) Whole embryo in 100\% RNAlater. The area for microdissection is indicated with the rectangle. (D) Embryonic flanks microdissected in 100\% RNAlater. (E) A higher magnification of a flank in 100\% RNAlater shows invisibility of the mammary rudiments under these conditions. (F) Visibility of mammary buds (arrows) after 5 minutes partial rehydration in 40\% RNAlater in DEPC-PBS ${ }^{++}$. (G) Ectoderm was easily peeled off and folded back over the mesenchyme. Mammary buds are numbered in black, with number 1, 2, 4, and 5 still attached to the ectoderm, while number 3 had remained behind in the mesenchyme from which it was subsequently released. Light circular areas 1', 2' and 3' are cup shaped cavities in the mesenchyme where mammary rudiments 1, 2 and 3 resided prior to tissue separation. (H) Completely isolated mammary buds and their adjacent ectoderm and mesenchyme. (I-J) Microdissection of whisker follicles (yellow open arrow). (K-L) Microdissection of submandibular salivary gland (s) and tooth buds (in, incisor; mo, molar). Bud, mammary bud; DM, dermal mesenchyme; Ect, surface ectoderm; Mes, mesenchyme. Scale bars: (A,B) 50 um; (C,D) $500 \mu \mathrm{m}$; (E-L) $200 \mu \mathrm{m}$ 
All techniques were performed per manufacturers'instructions. Microarray data from five independent pools of each tissue were analyzed using the Partek Genomics Suite (Partek).

\section{$R T-P C R$}

Total RNA was isolated from E12.5 microdissected tissues as described above. cDNA was prepared from $10 \mathrm{ng}$ of total RNA using the SuperScript ${ }^{\circledR}$ III First-Strand Synthesis System (Invitrogen). $0.5 \mu$ l of the amplified cDNA was used in each PCR reaction under the following conditions: $94^{\circ} \mathrm{C}$ for $5 \mathrm{~min}$; 30 cycles of 94 ${ }^{\circ} \mathrm{C}$ for $30 \mathrm{sec}, 58^{\circ} \mathrm{C}$ for $30 \mathrm{sec}, 72^{\circ} \mathrm{C}$ for $1 \mathrm{~min} ; 72^{\circ} \mathrm{C}$ for $10 \mathrm{~min}$. $\beta$-actin was used as the internal control. Sequences of primers were listed in Table 1. Forward (F) primer and Reverse $(R)$ primer are located at different exons, to distinguish between cDNA-based amplicons and genomic DNA based amplicons (if any).

\section{Immuno-detection of protein expression}

Paraffin sections of $4 \%$ PFA-fixed embryos were subjected to a standard immunohistochemistry protocol with citrate-based antigen retrieval preceding incubation with rabbit anti-Androgen receptor (1:100, Millipore), donkey anti-rabbit HRP (1:500, Jackson Laboratories) and the substrate diaminobenzidine (DAB).

The ectoderm with attached mammary buds was peeled off the embryonic flank using our new method; spread and pinched on a polyethylene tissue culture coverslip (Sarstedt); rinsed with PBS; and fixed with $4 \%$ PFA for $15 \mathrm{~min}$. The tissue was then blocked for $1 \mathrm{~h}$ at room temperature with $5 \%$ goat serum $/ 0.1 \%$ Triton $\mathrm{X}-100$ and incubated with rabbit anti-Keratin 5 (1:1000, Covance) and rat anti-E-cadherin (1:200, Invitrogen) at $4^{\circ} \mathrm{C}$ overnight. After a wash with PBS, the ectoderm was incubated with Alexa Fluor 546 donkey anti-rabbit lgG and Alexa Fluor 488 donkey anti-rat (1:200, Invitrogen) for 1 h at room temperature. The staining was observed with the Olympus FluoView ${ }^{\mathrm{TM}}$ FV1000 Confocal Microscope.

\section{Results and Discussion}

To preserve the transcriptome as similar as possible to the status quo in utero and prevent experimentally induced transcriptional changes, we collected whole mouse embryos in RNAlater, which limits RNA degradation and transcription by quickly permeating tissue and denaturing cellular proteins (http://www.ambion.com/ techlib/prot/bp_7020.pdf). However, RNAlater severely dehydrated the embryo (Fig. 1C), therewith interfering with the visibility and separation of structures, especially those as small as e.g. E12.5 mammary buds. To overcome this obstacle, we incubated tissues at varying ratios of RNAlater:DEPC-PBS ${ }^{+/}$, and found that a 4:6 volume ratio, i.e. $40 \%$ RNAlater, provides sufficient rehydration to visualize the mammary rudiments. By then, adhesion between epithelia and mesenchyme was also weakened, facilitating easy microsurgical separation of the buds, ectoderm and mesenchyme
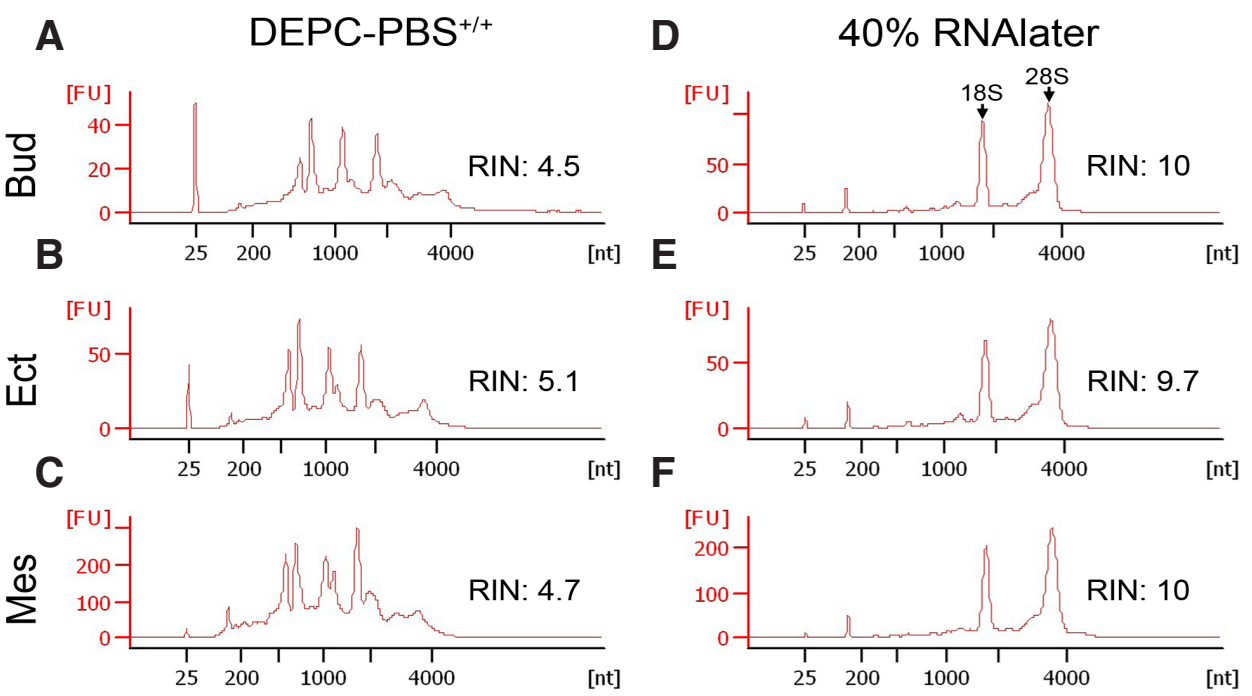

G

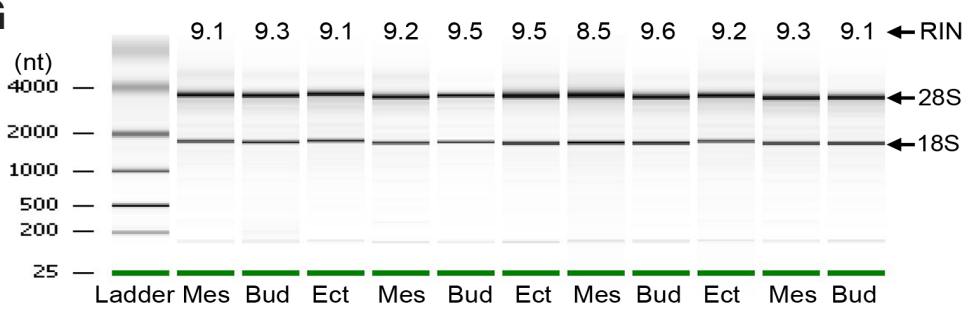

Fig. 2. RNA quality analyzed on Agilent RNA 6000 Pico Chips. (A-F) RNA quality of samples rehydrated in DEPC-PBS ${ }^{+++}$(A-C) or 40\% RNAlater (D-F). The $y$-axis of the electropherograms represents RNA fluorescence units [FU], and the x-axis represents the nucleotide [nt] length of the RNA. (G) Electrophoresis map generated by the Agilent bioanalyzer showing the consistently excellent RNA quality obtained by our microdissection method in 40\% RNAlater. Ect, surface ectoderm; Mes, mesenchyme; Bud, mammary bud. from each other (Fig. 1G-H). With this method, a trained person can dissect all tissue samples from one flank within 10 minutes. Other ectodermal appendages, such as whisker follicles, submandibular salivary glands and teeth at bud stage at E12.5 (Fig. 1I-L) and E13.5, and other organs such as dorsal root ganglia, emerging ribs, bones and large vessels, can be equally easily dissected from their surrounding tissues. Thus, our method of tissue collection is rapid, easy and transferable to a broad range of tissues.

To assess whether $40 \%$ RNAlater can protect RNA from degradation, we rehydrated the flanks in DEPC-PBS ${ }^{+/+}$ only or in $40 \%$ RNAlater. Tissues dissected from flanks in DEPC-PBS ${ }^{+/+}$ yielded RNA with RNA Integrity Numbers (RINs) between 4 and 5, indicating RNA breakdown (Fig. 2A-C). However, tissues that were dissected in $40 \%$ RNAlater consistently yielded RIN values above 9 , or even reaching the maximum of 10 , indicating that RNA is preserved in excellent quality with this dissection method (Fig. 2D-G). Thus, the use of $40 \%$ RNAlater nicely combines the need for tissue rehydration and visualization with retention of an excellent RNA integrity.

The purity (i.e. tissue specificity) 
A

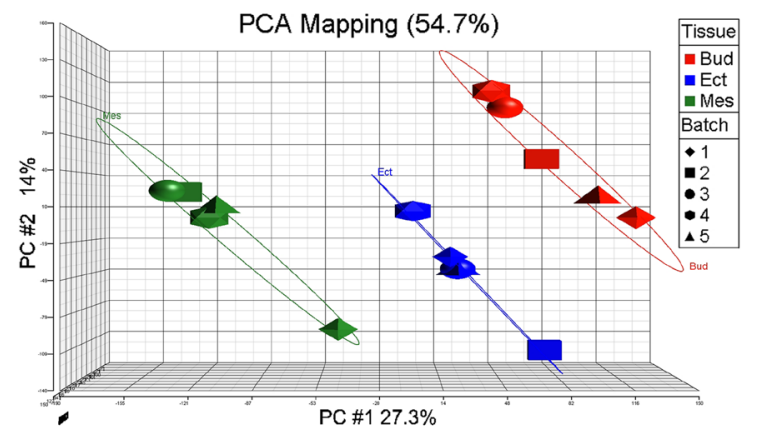

C

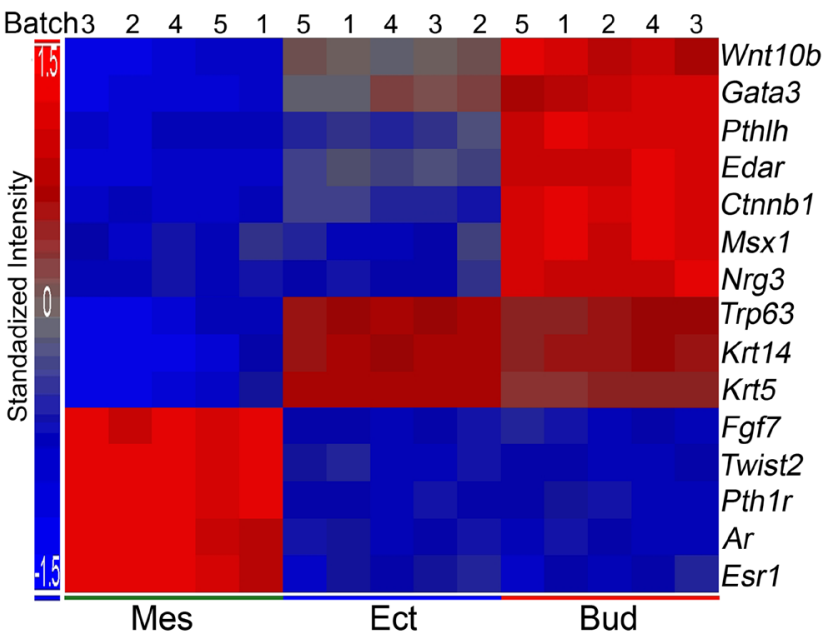

B
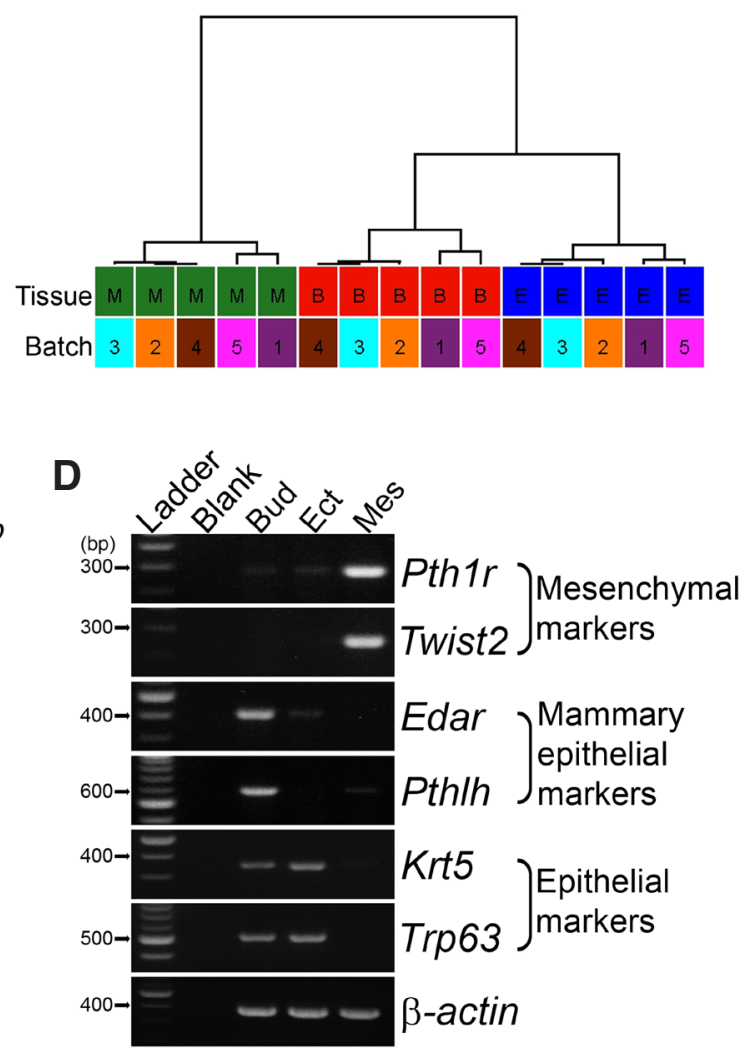

Fig. 3. Gene expression analysis revealed specificity and efficiency of microdissection. (A-C) Microarray analysis of 5 independent pools of E12.5 mammary buds (B or Bud), adjacent surface ectoderm (E or Ect) and mesenchyme (M or Mes). (A) PCA analysis and (B) hierarchical clustering grouped samples by tissue regardless of batch. (C) Clustering analysis of microarray data and (D) RT-PCR analysis of RNA from E12.5 mammary buds, adjacent ectoderm and mesenchyme show the correct tissue-specific expression patterns of known markers for mammary epithelium, epithelium, or mesenchyme. Ladder: 100 bp ladder.

of input RNA is another key factor for accurate gene expression profiling. We had dissected the mammary buds, ectoderm and mesenchyme without visible adhering neighbouring tissues (Fig. $1 \mathrm{H}$ ), suggesting that the extracted RNA samples would be pure. We verified the purity by using the RNA samples of five independent pools of each tissue type for gene expression analysis via cDNA microarrays. Principal component analysis (PCA) (Fig. 3A) and hierarchical clustering (Fig. $3 \mathrm{~B}$ ), both grouped samples by tissue type without batch effect, indicating an effective separation of mammary buds, ectoderm and mesenchyme. The effective separation was furthermore suggested by the hierarchy map showing that the expression profile of mammary buds is closer to ectoderm than to mesenchyme (Fig. 3B), which is in accordance with the mammary gland being derived from the ectoderm (Cunha and Hom, 1996). These results may suggest that tissue cross-contamination was minimal to non-existent.

Individual gene expression analysis revealed that the relative expression of known early mammary epithelial markers such as Wnt10b (Veltmaat etal., 2004), Gata3 (Asselin-Labat et al., 2007), Nrg3 (Howard et al., 2005), Pthlh (Dunbar et al., 1999), Edar (Pispa et al., 2003), Msx1 (Phippard et al., 1996), and $\beta$-catenin (Chu et al., 2004), was indeed high in the mammary bud samples.
Furthermore, expression of genes known to be expressed in the dermal and mammary mesenchyme such as Fgf7, Pthlh receptor (Pth1r), Twist2, or in the mammary mesenchyme only, such as Estrogen receptor (Esr1) and Androgen receptor (Ar) (Dillon et al., 2004, Dunbar et al., 1999, Heckman et al., 2007, Li et al., 1995), was high in the mesenchymal samples (Fig. 3C). Finally, expression of Trp63, Krt5 and Krt14, all markers for stratified epithelium, was high in both the mammary bud and ectoderm but not the mesenchymal samples (Byrne et al., 1994, Mills et al., 1999), all as expected. RT-PCR of six tissue-specific markers yielded amplicons in the expected tissue-specific manner (Fig. 3D), further confirming the high tissue purity, as already suggested by visual inspection.

Immunofluorescent detection of E-cadherin and Keratin5, wellknown markers of the ectoderm and mammary rudiments, shows that harvest and storage of specimens in RNAlater is compatible with epitope recognition by antibodies (Fig. 4). Therefore, this method of tissue separation may also be useful for the confirmation of gene expression data at the level of protein expression in situ, as it may render specimens sufficiently thin and transparent for direct use in e.g. confocal microscopy and as such prevent the need for tissue sectioning. In conclusion, this novel tissue 

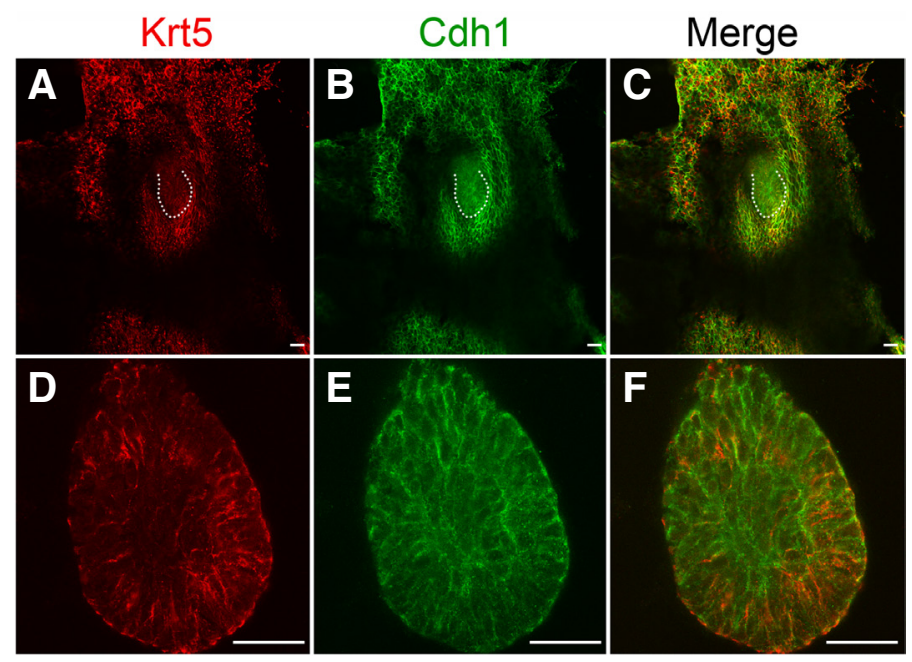

Fig. 4. Immunofluorescent staining of microdissected ectoderm with mammary rudiments. Confocal microscopy images of immunofluorescent detection of Keratin 5 (Krt5, red) and E-cadherin (Cdh1, green). (A-C) Low magnification of E12.5 ectoderm with a mammary bud attached. The boundary of mammary rudiment is indicated by the white dashed line. (D-F) High magnification of the mammary bud. (C, F) Merge of Keratin 5 and E-cadherin expression profiles. Scale bar: $30 \mu \mathrm{m}$.

separation technique will greatly facilitate research pertaining to the molecular regulation of organ and tissue formation.

\section{Acknowledgements}

The authors declare no competing interests, and thank the Biomedical Research Council of A*STAR (Agency for Science, Technology and Research), Singapore for funding, and Prof. Jean Paul Thiery and Ms. Wen Jing Sim for technical advice.

\section{References}

AMIT, I., CITRI, A., SHAY, T., LU, Y., KATZ, M., ZHANG, F., TARCIC, G., SIWAK, D., LAHAD, J., JACOB-HIRSCH, J. et al., (2007). A module of negative feedback regulators defines growth factor signaling. Nat Genet 39: 503-512.

ASSELIN-LABAT, M.L., SUTHERLAND, K.D., BARKER, H., THOMAS, R., SHACKLETON, M., FORREST, N.C., HARTLEY, L., ROBB, L., GROSVELD, F.G., VAN DER WEES, J. et al.,(2007). Gata-3 is an essential regulator of mammary-gland morphogenesis and luminal-cell differentiation. Nat Cell Biol 9: 201-209.

BYRNE, C., TAINSKY, M. and FUCHS, E. (1994). Programming gene expression in developing epidermis. Development 120: 2369-2383.

CHU, E.Y., HENS, J., ANDL, T., KAIRO, A., YAMAGUCHI, T.P., BRISKEN, C., GLICK, A., WYSOLMERSKI, J.J. and MILLAR, S.E. (2004). Canonical WNT signaling promotes mammary placode development and is essential for initiation of mammary gland morphogenesis. Development 131: 4819-4829.
COPOIS, V., BIBEAU, F., BASCOUL-MOLLEVI, C., SALVETAT, N., CHALBOS, P., BAREIL, C., CANDEIL, L., FRASLON, C., CONSEILLER, E., GRANCI, V. et al., (2007). Impact of RNA degradation on gene expression profiles: assessment of different methods to reliably determine RNA quality. J Biotechnol 127: 549-559.

CUNHA, G.R. and HOM, Y.K. (1996). Role of mesenchymal-epithelial interactions in mammary gland development. J Mammary Gland Biol Neoplasia 1: 21-35.

DILLON, C., SPENCER-DENE, B. and DICKSON, C. (2004). A crucial role for fibroblast growth factor signaling in embryonic mammary gland development. J Mammary Gland Biol Neoplasia 9: 207-215.

DUNBAR, M.E., DANN, P.R., ROBINSON, G.W., HENNIGHAUSEN, L., ZHANG, J.P. and WYSOLMERSKI, J.J. (1999). Parathyroid hormone-related protein signaling is necessary for sexual dimorphism during embryonic mammary development. Development 126: 3485-3493.

EMMERT-BUCK, M.R., BONNER, R.F., SMITH, P.D., CHUAQUI, R.F., ZHUANG, Z., GOLDSTEIN, S.R., WEISS, R.A. and LIOTTA, L.A. (1996). Laser capture microdissection. Science 274: 998-1001.

HECKMAN, B.M., CHAKRAVARTY, G., VARGO-GOGOLA, T., GONZALES-RIMBAU, M., HADSELL, D.L., LEE, A.V., SETTLEMAN, J. and ROSEN, J.M. (2007). Crosstalk between the p190-B RhoGAP and IGF signaling pathways is required for embryonic mammary bud development. Dev Biol 309: 137-149.

HOWARD, B., PANCHAL, H., MCCARTHY, A. and ASHWORTH, A. (2005). Identification of the scaramanga gene implicates Neuregulin3 in mammary gland specification. Genes Dev 19: 2078-2090.

KRATOCHWIL, K. and SCHWARTZ, P. (1976). Tissue interaction in androgen response of embryonic mammary rudiment of mouse: identification of target tissue for testosterone. Proc Natl Acad Sci USA 73: 4041-4044.

LEE, M.Y., RACINE, V., JAGADPRAMANA, P., SUN, L., YU, W., DU, T., SPENCERDENE, B., RUBIN, N., LE, L., NDIAYE, D. et al., (2011). Ectodermal Influx and Cell Hypertrophy Provide Early Growth for All Murine Mammary Rudiments, and Are Differentially Regulated among Them by Gli3. PLoS One 6: e26242.

LI, L., CSERJESI, P. and OLSON, E.N. (1995). Dermo-1: a novel twist-related bHLH protein expressed in the developing dermis. Dev Biol 172: 280-92.

MIKKOLA, M.L. (2007). Genetic basis of skin appendage development. Semin Cell Dev Biol 18: 225-236.

MILLS, A.A., ZHENG, B., WANG, X.J., VOGEL, H., ROOP, D.R. and BRADLEY, A (1999). p63 is a p53 homologue required for limb and epidermal morphogenesis. Nature 398: 708-713.

PHIPPARD, D.J., WEBER-HALL, S.J., SHARPE, P.T., NAYLOR, M.S., JAYATALAKE, H., MAAS, R., WOO, I., ROBERTS-CLARK, D., FRANCIS-WEST, P.H., LIU, Y.H. et al., (1996). Regulation of Msx-1, Msx-2, Bmp-2 and Bmp-4 during foetal and postnatal mammary gland development. Development 122: 2729-2737.

PISPA, J., MIKKOLA, M.L., MUSTONEN, T. and THESLEFF, I. (2003). Ectodysplasin Edar and TNFRSF19 are expressed in complementary and overlapping patterns during mouse embryogenesis. Gene Expr Patterns 3: 675-679.

TUCKER, A.S. (2007). Salivary gland development. Semin Cell Dev Biol 18: 237-244.

VELTMAAT, J.M., MAILLEUX, A.A., THIERY, J.P. and BELLUSCI, S. (2003). Mouse embryonic mammogenesis as a model for the molecular regulation of pattern formation. Differentiation 71: 1-17.

VELTMAAT, J.M., VAN VEELEN, W., THIERY, J.P. and BELLUSCI, S. (2004). Identification of the mammary line in mouse by Wnt10b expression. Dev Dyn 229: 349-356.

WANSBURY, O., MACKAY, A., KOGATA, N., MITSOPOULOS, C., KENDRICK, H., DAVIDSON, K., RUHRBERG, C., REIS-FILHO, J.S., SMALLEY, M.J., ZVELEBIL, M. et al., (2011). Transcriptome analysis of embryonic mammary cells reveals insights into mammary lineage establishment. Breast Cancer Res 13: R79. 


\section{Further Related Reading, published previously in the Int. J. Dev. Biol.}

Sox17-dependent gene expression and early heart and gut development in Sox17-deficient mouse embryos Sabine Pfister, Vanessa J. Jones, Melinda Power, Germaine L. Truisi, Poh-Lynn Khoo, Kirsten A. Steiner, Masami Kanai-Azuma, Yoshiakira Kanai, Patrick P. L. Tam and David A. F. Loebel Int. J. Dev. Biol. (2011) 55: 45-58

Gene expression profiling identifies eleven DNA repair genes down-regulated during mouse neural crest cell migration Domenico Albino, Antonella Brizzolara, Stefano Moretti, Carla Falugi, Valentina Mirisola, Paola Scaruffi, Michele Di Candia, Mauro Truini, Simona Coco, Stefano Bonassi and Gian Paolo Tonini Int. J. Dev. Biol. (2011) 55: 65-72

Over-expression of thymosin beta4 promotes abnormal tooth development and stimulation of hair growth Hee-Jae Cha, Deborah Philp, Soo-Hyun Lee, Hye-Sung Moon, Hynda K. Kleinman and Takashi Nakamura Int. J. Dev. Biol. (2010) 54: 135-140

Expression patterns of Src-family tyrosine kinases during Xenopus laevis development Zoltan Ferjentsik, Radek Sindelka, Jiri Jonak Int. J. Dev. Biol. (2009) 53: 163-168

Detection of differentially expressed genes in the early developmental stage of the mouse mandible.

H Yamaza, K Matsuo, T Kiyoshima, N Shigemura, I Kobayashi, H Wada, A Akamime and H Sakai

Int. J. Dev. Biol. (2001) 45: 675-680

Snail is an immediate early target gene of parathyroid hormone related peptide signaling in parietal endoderm formation. J M Veltmaat, C C Orelio, D Ward-Van Oostwaard, M A Van Rooijen, C L Mummery and L H Defize Int. J. Dev. Biol. (2000) 44: 297-307

Analysis of tenascin mRNA expression in the murine mammary gland from embryogenesis to carcinogenesis: an in situ hybridization study.

I Kalembey, T Yoshida, K Iriyama and T Sakakura

Int. J. Dev. Biol. (1997) 41: 569-573

Alterations in biosynthetic accumulation of collagen types I and III during growth and morphogenesis of embryonic mouse salivary glands.

P Hardman and B S Spooner

Int. J. Dev. Biol. (1992) 36: 423-427

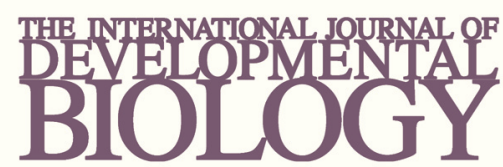

Volume 54 Nos. 6/7
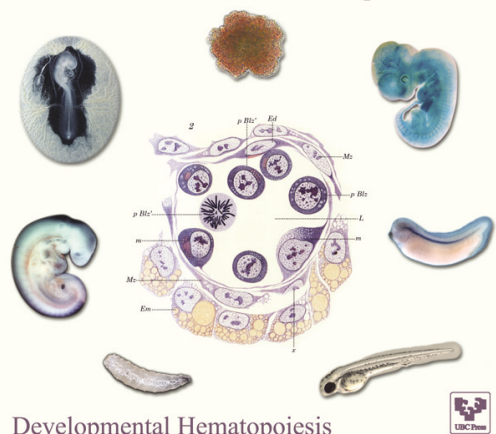

Developmental Hematopoiesis
5 yr ISI Impact Factor $(2010)=2.961$
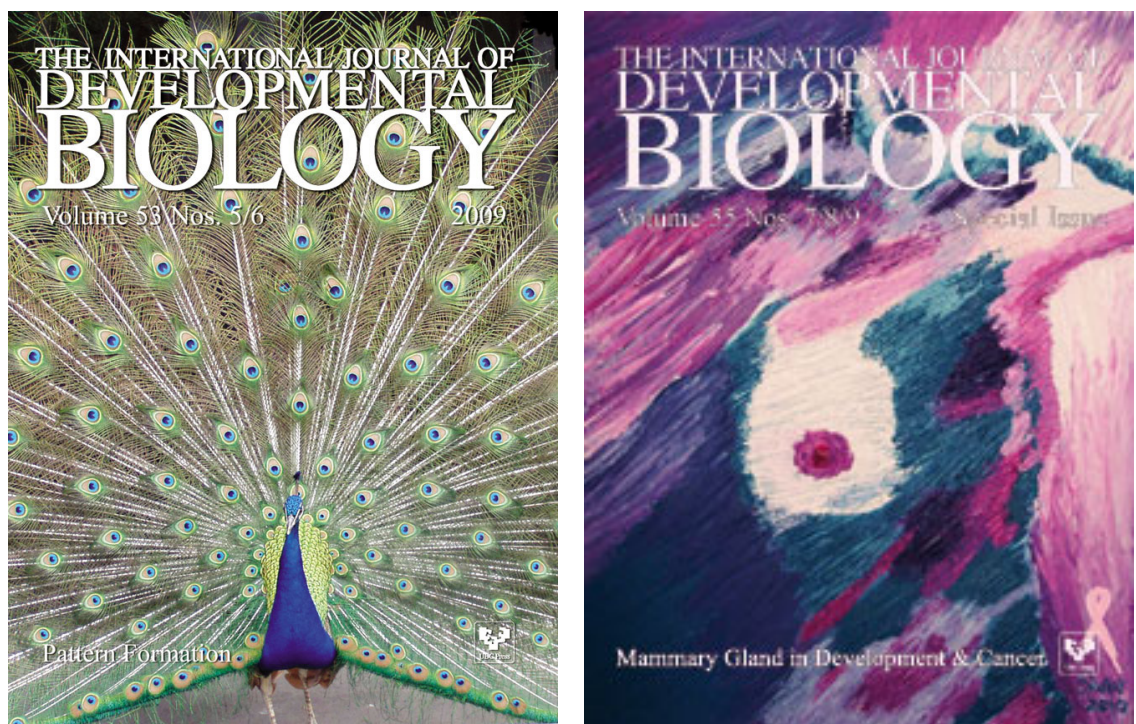